\title{
Fossil angiosperm wood and its host deposits from the periphery of a dominantly effusive ancient volcano (Doupovské hory Volcanic Complex, Oligocene-Lower Miocene, Czech Republic): systematics, volcanology, geochronology and taphonomy
}

\author{
JAKUB SAKALA, VLADISLAV RAPPRICH \& ZOLTÁN PÉCSKAY
}

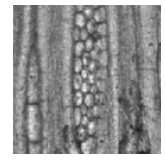

\begin{abstract}
A variety of fossil woods occur on the northern margin of the Doupovske hory Volcanic Complex in the northwestern part of the Czech Republic. The woods were buried by three different processes reflecting three different settings. First, a large area between the towns of Kadaň and Klášterec is covered by an up to $100 \mathrm{~m}$ thick sequence of lahar and debris avalanche deposits. These flows and avalanches gathered wood of Liriodendron, Lauraceae, Platanus, Cercidiphyllum, ?Craigia and Styracaceae from both the volcanic complex slopes and adjacent plains. Second, a rich assemblage of fossil woods with thermophilous elements such as Lauraceae and palms was preserved on the northern volcanic complex periphery by a Strombolian eruption of a monogenic cone. Third, a shallow lake formed to the side of the volcanic complex, where Platanus trunks were fossilized in the travertine. The wood of Liriodendron has never been previously recorded in the localities representing volcanic complex foothills, but is common in the local lahar deposits. This distribution leads us to hypothesize that Liriodendron forests dominated higher topographic levels of the Doupovské hory Volcanic Complex, reaching, but probably not exceeding $1000 \mathrm{~m}$ a.s.l. $\bullet$ Key words: fossil angiosperm wood, systematic palaeobotany, volcanology, taphonomy, geochronology, Tertiary, Czech Republic.
\end{abstract}

SAKALA, J., RAPPRICH, V. \& PÉCSKAY, Z. 2010. Fossil angiosperm wood and its host deposits from the periphery of a dominantly effusive ancient volcano (Doupovské hory Volcanic Complex, Oligocene-Lower Miocene, Czech Republic): systematics, volcanology, geochronology and taphonomy. Bulletin of Geosciences 85(4), 617-629 (5 figures). Czech Geological Survey, Prague. ISSN 1214-1119. Manuscript received April 21, 2010; accepted in revised form September 22, 2010; published online November 12, 2010; issued December 20, 2010.

Jakub Sakala, Charles University, Faculty of Science, Institute of Geology and Palaeontology, Albertov 6, 12843 Praha 2, Czech Republic; rade@natur.cuni.cz・Vladislav Rapprich, Czech Geological Survey, Klárov 3, 11821 Prague, Czech Republic; vladislav.rapprich@geology.cz・Zoltán Pécskay, Institute of Nuclear Research, Hungarian Academy of Sciences, Bem tér 18/C, H-4001 Debrecen, Hungary; pecskay@namafia.atomki.hu

Volcanic areas often provide excellent settings for preservation of fossil material, especially producing when fine pyroclastic material predominate. Effusive volcanic activity is much less conducive to the fossilization of organic material. Lava-built volcanoes and volcanic complexes undergo weathering and solid rock decay processes. Weathering products may substitute the role of pyroclastic deposits in dominantly effusive volcanoes. Consequently in combination with the topography, debris avalanches, debris flows and mudflows may be produced. Such secondary sedimentary processes bury remains of both fauna and flora (e.g., Cameron \& Pringle 1986).

Fossil wood is relatively common in the Tertiary of the northwestern part of the Czech Republic. Most are Cupressaceae s.l. (e.g., Teodoridis \& Sakala 2008). Angiosperm wood is frequently found in the town of Kadaň and its vicinity, related to Oligocene to early Miocene activity of the Doupovské hory Volcanic Complex (DHVC in the following text). Prakash et al. (1971) and Sakala \& Privé-Gill (2004) described eight different wood types from this area, hence the locality is one of the richest sites of fossil angiosperm wood in Central Europe (Sakala 2006, 2007). Temporary exposures excavated in the last fifteen years, including construction of the new hospital and digging activity for gas pipe and gas-fixtures in Kadaň, offered the opportunity for new sampling and reassessment of the taphonomic model for the area which was believed to have been dominated by diatreme facies of maar volcanoes (e.g., Kopecký 2010). The aim of our research is to understand how wood fragments were fossilized in settings of a dominantly effusive volcanic complex. 




Figure 1. Location of the Doupovské hory Volcanic Complex.

\section{Geological setting}

The origin of the Doupovské hory Volcanic Complex (DHVC - Fig. 1) is associated with the formation of the continental Eger (Ohře) Graben and ascent of mantle derived melts (e.g., Ulrych et al. 2002) along the boundary between the Saxothuringian and Teplá-Barrandian Domains of the Bohemian massif (Mlčoch 2003). A complex mosaic of crystalline rocks (including amphibolite, paragneisse, orthogneisse, granulite, phylite, variscan granite, etc.) form the basement of the DHVC (Mlčoch \& Konopásek 2010). The entire DHVC represents an erosional relic of a multiphase volcanic complex. Activity was initiated in the earliest Oligocene (mammal zone MP-21: Fejfar \& Kaiser 2005). The early DHVC fine-grained volcaniclastics were produced by basaltic eruptions of the Strombolian and phreato-magmatic style. Pyroclastic material from this activity was deposited in subaerial, swampy and lacustrine environments with a total thickness reaching $80 \mathrm{~m}$ (Hradecký 1997a). These deposits currently crop out on the eastern and northeastern margins of the DHVC. The volcanic activity later became predominantly effusive in character (Rapprich \& Holub 2008), associated with weak Strombolian and possibly also Hawaiian eruptions. The effusive ac- tivity continued until the Early Miocene ( $c$ a 29-22 Ma: Rapprich \& Holub 2008). This younger stage formed an extensive complex of foidite/basanite/tephrite lava sequences up to 500 m thick (Hradecký 1997a, Rapprich \& Holub 2008). Individual lava units are often accompanied by volcaniclastic debrites. These coarse grained sediments are interpreted as lahar or debris avalanche deposits (e.g., Hradecký 1997b). Hradecký (1997b) described these accumulations from the southern and western margins of the DHVC. In addition, we have documented lahar deposits also on the northern margins of the DHVC. Generally, the lahar deposits occur in various stratigraphic positions within the DHVC, but the debrites on the northeastern margins pre-date the lavas of the Úhošt Hill (Rapprich 2007). The oldest lava at the base of the Úhošt Hill was dated by the K-Ar method as $28.66 \pm 1.06 \mathrm{Ma}$ (Rapprich \& Holub 2008). On the northeastern periphery of the DHVC, a group of eroded remnants of monogenetic cones (23-20 Ma: this paper) occur and appear to represent the most recent volcanic activity of the DHVC in the Lower Miocene (Fig. 2). The sedimentary infill (including coal seams) of the Eger Graben shortly postdates the volcanic activity of the DHVC. This sedimentary period is represented to the northeast of the DHVC by the Miocene Most Basin. 


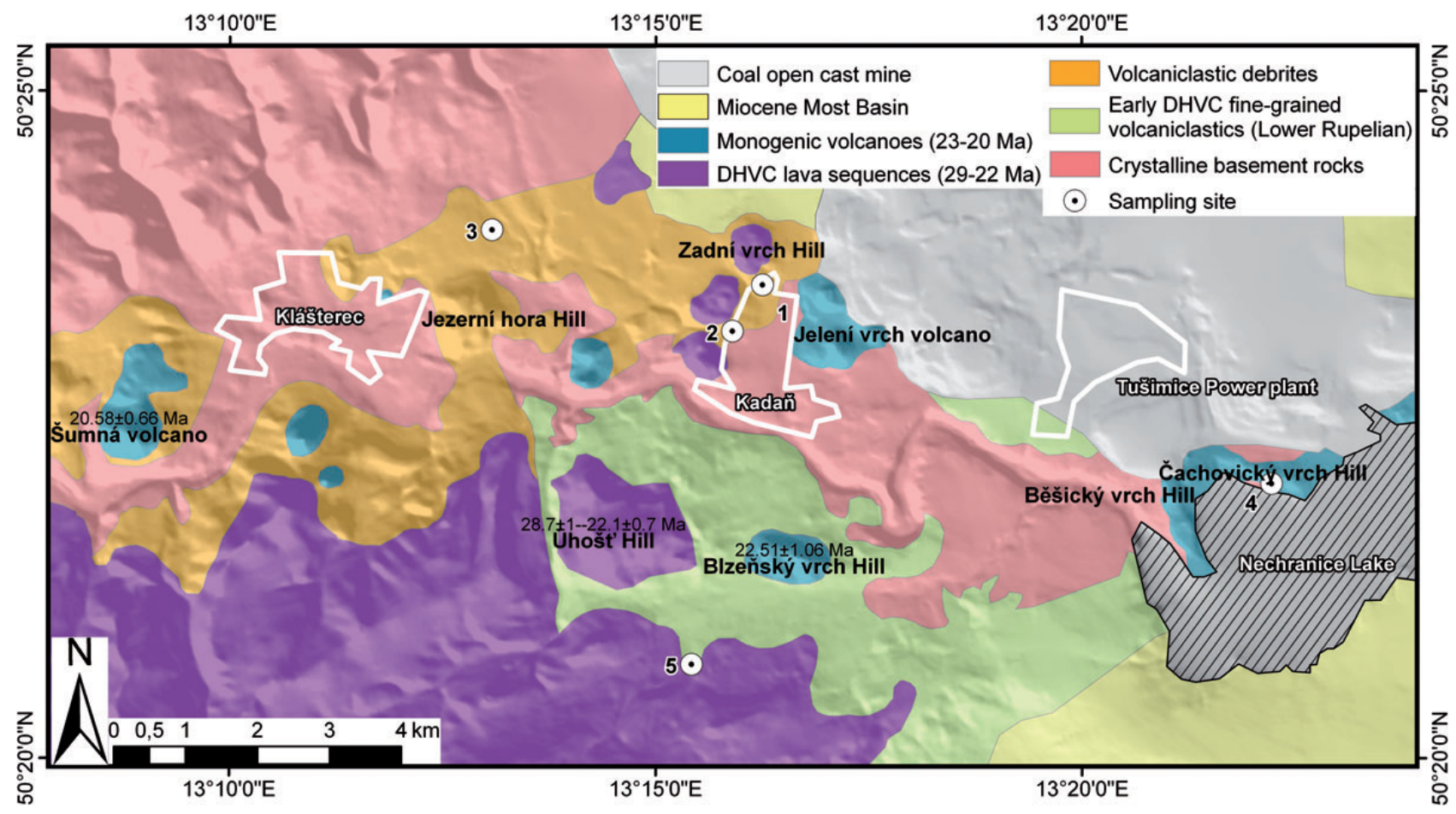

Figure 2. Simplified geological map of the northeastern periphery of the DHVC (adapted from the Digital Geological map of the Czech Republic $1: 50,000$ scale available on http://www.geology.cz/extranet/geodata/mapserver and modified with respect to new data and observations) and location of sampling sites: 1 - Zadní vrch Hill, 2 - Prostřední vrch Hill, 3 - Vernéřov, 4 - Nechranice, 5 - Zvoníčkov. Digital Elevation Model illuminated from southwest.

\section{Material and methods}

New specimens of silicified and calcified wood were thin-sectioned in compliance with the standard techniques and studied using compound light microscopy. Anatomical descriptions are in accordance with the IAWA Hardwood List (IAWA Committee 1989). The thin sections described here are partly housed in the National Museum in Prague (those described originally by Prakash et al. 1971 and epitype of Cercidiphylloxylon kadanense), and partly in the Chlupáč Museum of Earth History in the Faculty of Science of Charles University in Prague (new specimens).

The approximate age of the lahar deposits was determined by their position beneath a lava dated $28.66 \pm 1.06$ Ma (K-Ar: Rapprich \& Holub 2008), but the age of the monogenetic volcanism on the northern periphery of the DHVC was not known. Three samples of lavas from monogenic volcanoes (Šumná volcano, Blzeňský vrch Hill, Jelení vrch Hill) on the northern periphery of the DHVC were dated using the K-Ar method. All the three samples were measured as bulk-rocks. Additionally, glass and plagioclase fractions were separated from the groundmass of the Jelení vrch Hill sample to resolve the problem of low potassium content in the bulk-rock sample. Geochronological analyses were carried out in the
ATOMKI Laboratories, Debrecen, Hungary. Potassium concentration was measured using a digitized flame photometer, CORNING 480 machine with a Li internal standard. The analyses were controlled by inter-laboratory standards Asia 1/65, LP-6, HD-B1 and GL-O. Argon was extracted from the samples by high frequency induction heating. $\mathrm{A}^{38} \mathrm{Ar}$-spike was introduced into the system via a gas pipette before the degassing began. The isotopic ratios were measured on a $15 \mathrm{~cm}$ radius magnetic sector-type mass spectrometer under static mode, built in Debrecen, Hungary. Balogh (1985) and Odin (1982) described in detail the methods applied here. The calculation of ages was based on atomic constants suggested by Steiger \& Jäger (1977). Analytical errors are quoted for the $68 \%$ confidence level (one standard deviation).

\section{Systematic palaeobotany}

Angiosperm wood from the DHVC, both newly found specimens and those described by Prakash et al. (1971) and Sakala \& Privé-Gill (2004), can be subdivided into seven units called "wood types" sensu Wiemann et al. (1998, p. 85). These are listed using informal names and described in the following section. 


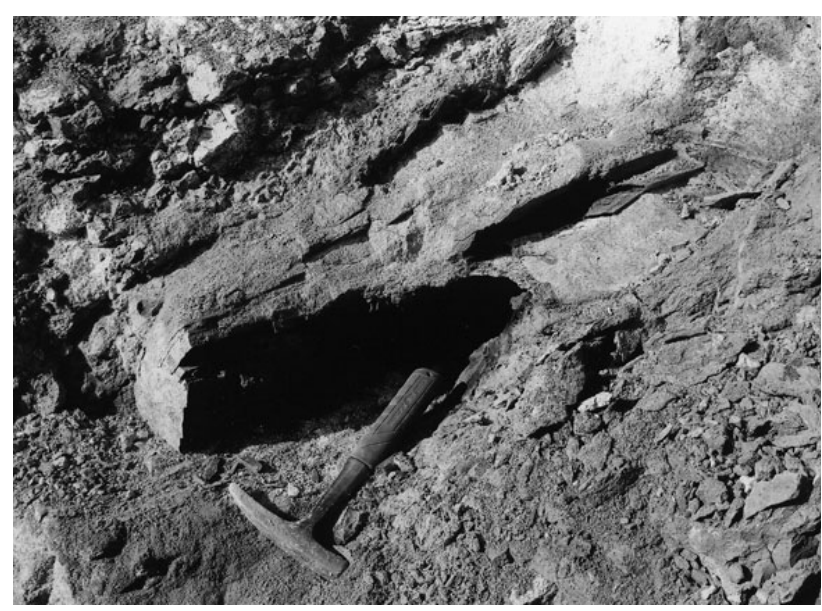

Figure 3. Calcified trunk of Liriodendron in the lahar deposits exposed during diggingwork for gas-pipes in Kadaň, southern slope of the Prostřední vrch Hill.

\section{Wood type 1 - Liriodendroxylon}

Family Magnoliaceae

\section{Genus Liriodendroxylon Prakash, Březinová \& Bůžek}

\section{Liriodendroxylon tulipiferum Prakash, Březinová \& Bůžek}

Figure 4A-C

Material. - Kadaň-Zadní vrch ZV-23 (holotype), 18/98, 53/02; Vernéřov 57/02, 61/02.

Description. -Wood diffuse-porous, growth ring boundaries distinct, vessels rarely solitary mostly in radial multiples and clusters, scalariform perforation plates with about 10 bars, opposite intervessel pits with oval outlines, slightly heterocellular rays mostly 3 - to 4-seriate, and marginal axial parenchyma.

Discussion. - Prakash et al. (1971) noted that this wood type was similar to modern Liriodendron tulipifera L. (see InsideWood 2004-onwards). Marginal parenchyma is visible in slide G4049 of the holotype specimen which includes both transverse and radial views (Fig. 4A). Other diagnostic features, such as oval opposite intervessel pits are visible in the holotype (Prakash et al. 1971, fig. 33) as well as in the new specimens, e.g., 18/98 (Fig. 4C). Leaves and fruits of Liriodendron are unknown from the DHVC, but there are occurrences of $\mathrm{Li}$ riodendron haueri in the České středohoří Mts (Kvaček \& Teodoridis 2007).

\section{Wood type 2 - Laurinoxylon}

Family Lauraceae

\section{Genus Laurinoxylon Felix emend. Dupéron et al.}

\section{Laurinoxylon czechense Prakash, Březinová \& Bůžek} Figure 4D-G

Material. - Kadaň-Zadní vrch CNB-2 (type); ?Nechranice 74/04.

Description. - Wood diffuse-porous, growth ring boundaries distinct, vessels mostly solitary and in radial (and oblique) multiples of 2-3, predominantly simple perforation plates, scalariform perforation plates with 10-15 bars rarely present in narrow vessel elements, heterocellular rays 1 - to 3 -seriate with some enlarged oil / mucilage cells in the margins, vasicentric axial parenchyma.

Discussion. - Dupéron-Laudoueneix \& Dupéron (2005) inventoried the fossil woods assigned to the Lauraceae. The original slides of Laurinoxylon diluviale (Unger) Felix, the type species of Laurinoxylon known since $16^{\text {th }}$ century as 'Sündfluthholz' from the phreatomagmatic vent breccia at Jáchymov (north of the DHVC, in the Krušné hory Mts/Erzgebirge), were re-discovered in the French Museum of Natural History (MNHN) in Paris and re-described, together with emended generic and specific diagnoses (Dupéron et al. 2008). The fossil wood briefly described here has characteristics of the morphogenus Laurinoxylon. Prakash et al. (1971) recognized it as a distinct

Figure 4. A-C - Wood type 1 - Liriodendroxylon (A, B: holotype ZV-23 of Liriodendroxylon tulipiferum; C: specimen 18/98). $・$ A - diffuse-porous wood with vessels rarely solitary, usually in multiples and terminal parenchyma in 3-seriate lines, TS/RLS. • B - slightly heterocellular rays mostly 3-4-seriate and scalariform perforation plates with about 10 bars, TLS. $\bullet$ C - opposite intervessel pits, RLS. - D-G - Wood type $2-$ Laurinoxylon (holotype CNB-2 of Laurinoxylon czechense). $\bullet$ D - diffuse-porous wood with paratracheal vasicentric parenchyma, TS. $\bullet$ E - heterocellular 1-3-seriate rays with swollen marginal cells, TLS. $\bullet \mathrm{F}$ - ray cells with oil or mucilage content in margin, RLS. $\bullet \mathrm{G}-$ detail of a small vessel element with alternate intervessel pits in lower part and scalariform perforation plate in upper part, TLS. - H-M - Wood type 3 - Platanus (H, K: holotype CNB-6 of Platanoxylon bohemicum; I, L, M: holotype ZV-24 of Spiroplatanoxylon europeanum; J: holotype CNB-11 of Dryoxylon bohemicum). • H-J - diffuse-porous wood with distinct growth rings and broad rays, TS. $\bullet \mathrm{K}-$ broad homocellular rays up to 20 cells wide, TLS. $\bullet$ L - detail of homocellular ray and exclusively scalariform perforation plates with about 20 bars, TLS. $\bullet$ M - helical thickening on the top of a vessel element, TLS. Scale bars $=500 \mu \mathrm{m}$ in $\mathrm{A}, \mathrm{B}, \mathrm{D}, \mathrm{H}-\mathrm{K} ; 200 \mu \mathrm{m}$ in $\mathrm{E}, \mathrm{F}, \mathrm{L} ; 50 \mu \mathrm{m}$ in $\mathrm{C}, \mathrm{G}, \mathrm{M}$. 

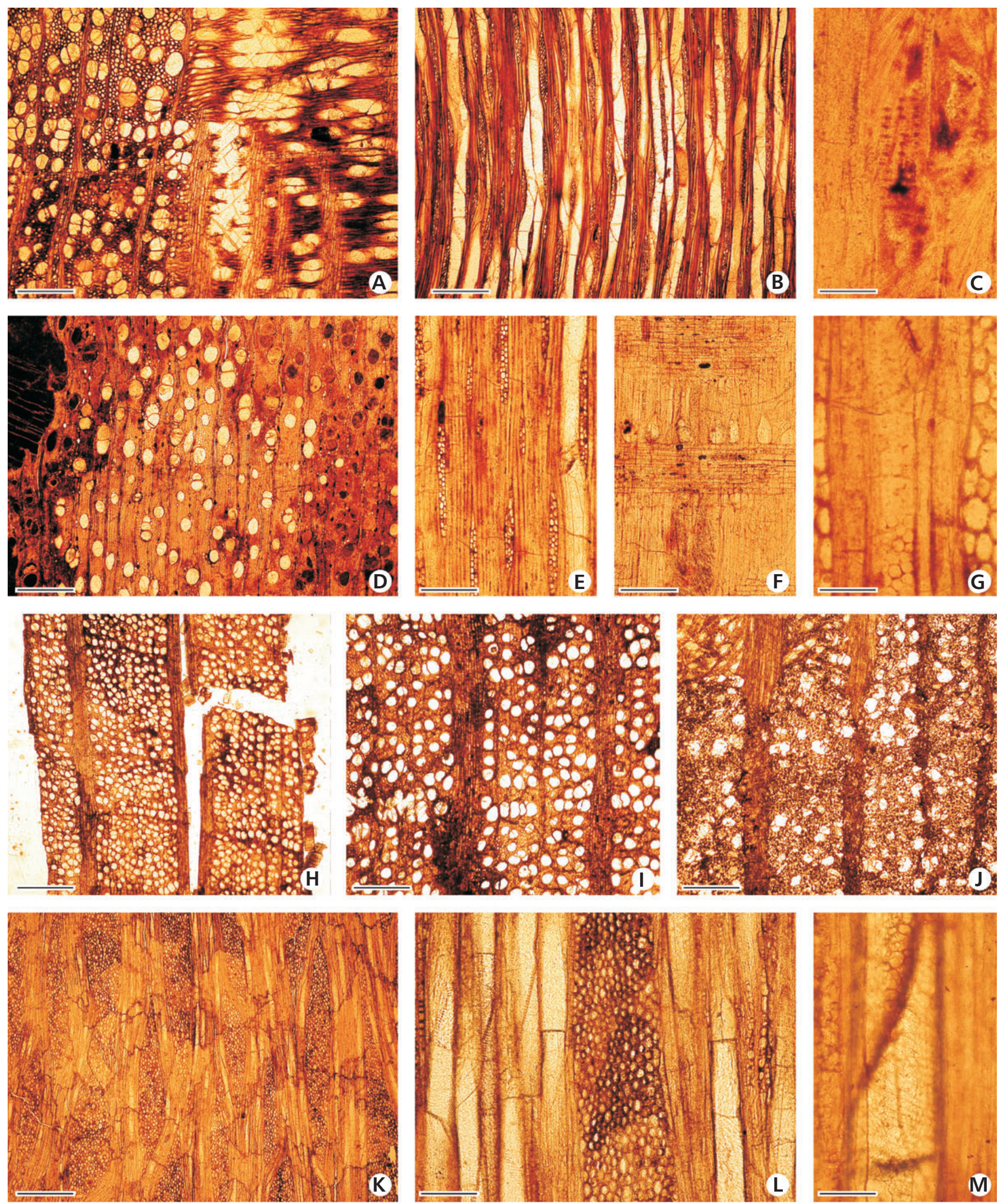
species L. czechense. It differs from L. diluviale in having generally thinner rays, mainly due to narrower individual ray cells. This difference in ray width can partly be explained by the processes of fossilization which could produce more dilated ray cells in L. diluviale (M. and J. Dupéron, pers. comm.). Contrary to Prakash et al. (1971), we observed oil cells similar to those in L. diluviale (Fig. 4E, F) associated with ray parenchyma only (but not those amongst fibres) and very rarely scalariform perforation plates in narrow vessel elements (Fig. 4G). Therefore, it is not easy to distinguish between these two species. Idioblasts (oil/mucilage cells) associated exclusively with rays are present in several taxa, e.g., Caryodaphnopsis, Litsea chinensis or the south-American species of Cinnamomum (Richter 1987). As vessel-ray pitting is not preserved, it is not possible to use correctly the classification sensu Richter (1987). As a result, we cannot attribute our wood to any particular living genus. The periphery of the DHVC has yielded thermophilous floras with Daphnogene (Kvaček \& Teodoridis 2007), which is considered to be related to the living Cinnamomum camphora (L.) J. Presl (Kvaček et al. 2004, Kvaček pers. comm.).

\section{Wood type 3 - Platanus}

Family Platanaceae

\section{Platanoxylon Andreánszky ex Prakash, Březinová \& Bůžek}

Platanoxylon bohemicum Prakash, Březinová \& Bůžek Figure 4H, K

1971 Platanoxylon bohemicum sp. nov.; Prakash, Březinová \& Bůžek, p. 115, pl. 39, figs 44, 46.

Material. - Kadaň-Zadní vrch CNB-6 (type), 73/03; ?Nechranice 109/05, 114/06; ?Vernéřov 64/02.

\section{Spiroplatanoxylon Süss}

\section{Spiroplatanoxylon europeanum (Prakash, Březinová \& Bůžek) Süss}

Figure 4I, L, M

1971 Plataninium europeanum sp. nov.; Prakash, Březinová \& Bůžek, p. 120, pl. 42, figs 59-63.

2007 Spiroplatanoxylon europeanum (Prakash, Březinová \& Bůžek) Süss comb. nov.; Süss, p. 12.

Material. - Kadaň-Zadní vrch ZV-24 (type, CNB-11).

\section{Dryoxylon Schleiden in Schmid}

\section{Dryoxylon bohemicum Prakash, Březinová \& Bůžek} Figure 4J

1971 Dryoxylon bohemicum sp. nov.; Prakash, Březinová \& Bůžek, p. 122, pl. 43, figs 64-67.

Material. - Kadaň-Zadní vrch CNB-11 (type).

Description. - Wood diffuse porous, growth ring boundaries distinct, vessels solitary or in short irregular multiples with scalariform perforation plates only (simple plates not observed) with about 20 bars, sometimes with spiral thickenings, homocellular rays up to 20 cells wide and apotracheal diffuse-in-aggregates and scanty paratracheal vasicentric axial parenchyma, rarely crystalliferous.

Discussion. - The three species recognized by Prakash et al. (1971), i.e., Platanoxylon bohemicum, Plataninium europaeum (= Spiroplatanoxylon europeanum) and the very poorly preserved Dryoxylon bohemicum, are very similar to each other. They all have large homocellular rays, up to 24 cells wide, and scalariform perforation plates. Although there are several differences between them (e.g., smaller vessel elements in Platanoxylon bohemicum type species) they all seem to belong to the same type of platanoid wood whose exact affinity is uncertain. We think the wood must be related to Platanus neptuni (Ettingsh.) Bůžek, Holý \& Z. Kvaček (Sakala 2006, Kvaček \& Manchester 2004), the only member of the Platanaceae present in both volcanic areas of the DHVC and the České středohoří Mts (Kvaček $\&$ Teodoridis 2007). P. neptuni is otherwise known as a nearly complete plant based on foliage branches, isolated leaves, stipules, staminate inflorescences with pollen in situ and infructescences (Kvaček 2008). The specific systematic position of $P$. neptuni within Platanus is expressed by a distinct subgenus Glandulosa (see in Kvaček et al. 2001, table 1) and corresponds well to the specific character of our fossil wood (see here below).

The fossil wood related to Platanus is usually classified under the mophogenera Platanoxylon or Plataninium. As already noticed by Brett (1972) and Wheeler \& Manchester (2002, p. 97), the classification of fossil Platanus-like woods is not a simple matter because they generally differ from the extant Platanus. Firstly, fossil platanoid wood often has scalariform perforation plates only (Wheeler 1995). The only living representative of Platanus which bears some resemblence with respect to this feature i.e. having a higher portion of scalariform to simple perforation plates, is P. kerrii Gagnep., native to Laos and Vietnam (Wheeler 1995). Contrary to Prakash et al.'s (1971) description, and in accordance with Süss \& Müller-Stoll (1977, p. 50), we have not observed any simple perforation 
plates in our samples of platanoid wood. Secondly, as Süss \& Müller-Stoll (1977) described, some platanoid woods have spiral thickening in the vessel elements. This feature is unknown among extant Platanus woods (Wheeler \& Manchester 2002). Süss (2007) recently created a new morphogenus, Spiroplatanoxylon, for platanoid wood with spiral thickening and re-interpreted Platanoxylon and Plataninium from Kadaň as belonging to this genus. We can confirm the presence of spiral thickenings (Fig. 4M) and rare prismatic crystals in axial parenchyma cells in Plataninium but not in Platanoxylon. Therefore, we use the denomination Spiroplatanoxylon only for the Plataninium type of wood in which we observed spiral thickening and crystals; as a precaution, we also keep the three morphospecies as separated units. However, we think they all represent the same botanical species.

\section{Wood type 4 - Cercidiphylloxylon}

Family Cercidiphyllaceae

\section{Genus Cercidiphylloxylon Prakash, Březinová \& Bůžek}

\section{Cercidiphylloxylon kadanense Prakash, Březinová \& Bůžek}

Figure 5A, B

Material. - Kadaň-Zadní vrch ZV-12 (holotype), G8113 (= 23/98) (epitype).

Description. - Wood diffuse-porous, growth ring boundaries distinct, vessels mostly solitary, with angular outline, scalariform perforation plates with about 40 bars, heterocellular, mostly $2-3$-seriate rays with uniseriate marginal rows (tails), which sometimes interconnect several multiseriate ray portions.

Discussion. - This wood type was originally described by Prakash et al. (1971) and later reviewed in detail by Sakala \& Privé-Gill (2004) with the definition of an epitype and comparative study with the extant Cercidiphyllaceae and Hamamelidaceae. It was noticed that 1) Cercidiphylloxylon kadanense slightly differed from extant Cercidiphyllum Sieb. \& Zucc., 2) it was the oldest record of true Cercidiphyllum fossil wood and 3) an older record of Cercidiphyllum-like wood of Paleocene/Eocene age had to be related to extinct genera with leaves of Trochodendroides Berry emend. Crane and fruits of the Nyssidium-type (Sakala \& Privé-Gill 2004). Our fossil wood most probably is the wood of Cercidiphyllum crenatum (Unger) R.W. Brown which occurs in all Oligocene localities in the České středohoří Mts (Kvaček \& Teodoridis 2007). However, its occurrence in the DHVC has not been proven so far. C. crenatum is known as a nearly complete plant based on foliage, fruits, seeds, staminate inflorescences, and in situ pollen (Kvaček 2008).

\section{Wood type 5 - Ulmus}

Family Ulmaceae

\section{Genus Ulmus L.}

\section{Ulmus sp.}

Figure 5C

Material. - Nechranice 75/04.

Description. - A small branch, $2.5 \mathrm{~cm}$ in diameter, with bark preserved. Wood ring-porous, growth ring boundaries distinct, earlywood vessels mainly solitary, latewood vessels grouped, forming typical wavy tangential bands, wide exclusively homocellular rays.

Discussion. - This single piece of wood was already mentioned by Sakala (2006). Unfortunately, the very poor preservation only allows its safe attribution to elm wood thanks to the diagnostic pattern seen in cross-section and the homocellular rays seen in radial section. A comparison with the fossil elm wood described from Bílina (Sakala 2002) or with other Ulmaceae (Wheeler \& Manchester 2007 ) is not possible. In the Tertiary of northwestern Bohemia, the genus Ulmus is represented by 2 species: U. fischeri as leaves in volcanic areas of both the DHVC and the České středohoří Mts and U.pyramidalis in the Most Basin based on leaves and fruits (Kvaček \& Teodoridis 2007).

\section{Wood type 6 - ?Craigia}

Family Malvaceae s.1.

\section{Genus Craigia W.W. Smith \& W.E. Evans}

\section{aff. Craigia sp.}

Figure 5D-G

Material. - Kadaň-Zadní vrch 72/03; Nechranice 70/03, 78/03, 84/04, 89/04, 90/04.

Description. - Wood semi-ring porous, growth ring boundaries distinct, marked by marginal parenchyma, earlywood vessels solitary or in short radial multiples of 2-3, latewood vessels thick-walled, mainly in radial multiples of 2-3, both with simple perforation plates, strongly heterocellular rays up to 10 cells wide with tile cells of the Pterospermum type, apotracheal diffuse to 
diffuse-in-aggregates and paratracheal vasicentric axial parenchyma.

Discussion. - It was recently suggested by Sakala (2006) that this newly discovered fossil wood could be attributed to Malvaceae s.l. due to its diagnostic tile cells in the rays, and to the extant genus Craigia, whose wood was described by Manchester et al. (2006). Tile cells occur in Malvaceae s.l. and are sometimes cited as a rare example of synapomorphy based on wood anatomy (Olson 2005, p. 514); however, they are also present in several species of Hopea from the Dipterocarpaceae (order Malvales) (e.g., Manchester et al. 2006, Selmeier 2000, table 3). In fact, the Czech wood type is similar to both the extant Craigia and extinct Chattawaya Manchester (1980) in its vessel disposition and character of tile cells. Unfortunately, we did not observe any helical thickening typical of Cragia; the seemingly helically thickened vessels in one specimen (Fig. 5G) do not represent true spirals but only "coalescent apertures" of intervessel pits (E.A. Wheeler, pers. comm.). Among fossil representatives, the helical thickening is only present in Reevesia japonoxyla Terada \& Suzuki (1998). On the other hand, we did not observe crystals, which are very typical of Chattawaya (Manchester 1980, Wheeler \& Manchester 2002). Therefore, we call our fossil wood "aff. Craigia sp.", reflecting the similarity to this genus except for the typical helical thickening. Although unknown in the DHVC, Craigia represents an important and abundant element in the České středohoří Mts and also in the Most and Sokolov basins (Kvaček \& Teodoridis 2007). It is generally present as dispersed fruit valves, but also as complete fruits at various stages of maturity, dispersed flowers and flower buds with pollen in situ, often together with the accompanying foliage of Dombeyopsis lobata (Kvaček 2008).

\section{Wood type 7 - Coryloxylon}

Family Styracaceae

\section{Genus Coryloxylon Prakash, Březinová \& Bůžek}

\section{Coryloxylon nemejcii Prakash, Březinová \& Bůžek Figure 5H-J}

1971 Coryloxylon nemejcii sp. nov.; Prakash, Březinová \& Bůžek, pp. 116-118, pl. 40, figs 48-52.

Material. - Kadaň-Zadní vrch CNB-4 (type).

\section{Coryloxylon tertiarum Prakash, Březinová \& Bůžek} Figure 5K-M

1971 Coryloxylon tertiarum sp. nov.; Prakash, Březinová \& Bůžek, pp. 118-120, pl. 41, figs 53-58.
Material. - Kadaň-Zadní vrch CNB-3 (type).

Description. - Wood diffuse porous, growth ring boundaries distinct, vessels solitary, but mostly in clusters and radial multiples, scalariform perforation plates with about 15-20 bars, heterocellular uniseriate and multiseriate (mostly 3- to 4-seriate) rays, axial parenchyma diffuse or diffuse-in-aggregates, chambered axial parenchyma with prismatic crystals often present.

Discussion. - The difference in vessel arrangement between Coryloxylon nemejcii and $C$. tertiarum do not seem to be systematically significant and can be explained by intraspecific or individual variability. We consider that both woods represent the same wood type, the affinities of which need re-evaluation. We did not observe the aggregate rays described by Prakash et al. (1971) so the connection to Corylus becomes questionable. Both woods have features seen in the Styracaceae: exclusively scalariform perforation plates, pores solitary or in multiples, both uniand multiseriate heterocellular rays, diffuse and diffuse-in-aggregates axial parenchyma and prismatic crystals or silica (Dickison \& Phend 1985). Prismatic crystals are useful for distinguishing between species within the extant Styracaceae. These are present only in Bruinsmia, Halesia and Styrax: Bruinsmia differs strongly from our wood in lacking growth rings, but a clear distinction between Halesia and Styrax is not possible based only on wood (Dickison \& Phend 1985). In the David A. Kribs wood collection housed in the N.C. State University, we observed similar structure in the extant Halesia macgregorii Chun (SJRw 29811) from China, however, it lacked crystals. Therefore, we are not able to distinguish between Styrax and Halesia. In the Tertiary of northwestern Bohemia, the only record of Styracaceae so far comes from the Early Miocene Cypris formation of the Sokolov Basin there are fruits designated as Sinojackia sp. by Bůžek et al. 1996 (recorded as Halesia crassa in Kvaček \& Teodoridis 2007).

\section{Volcanology and sedimentology}

Material for study was sampled from five localities (Fig. 2) representing three different volcanogenic sedimentary deposits:

\section{Zadní vrch, Prostřední vrch, Vernéřov (localities 1, 2 and 3 in Fig. 2)}

Localities 1, 2 and 3 are situated within the volcaniclastic debrites of the DHVC (Fig. 2). The localities were artificial trenches $($ length $\times$ width $\times$ depth $=10 \times 1 \times 1 \mathrm{~m}$ at 
Prostřední vrch) and earthworks (length $\times$ width $\times$ depth $=$ $300 \times 200 \times 2 \mathrm{~m}$ at Vernéřov, $300 \times 100 \times 1-3$ and $300 \times$ $200 \times 3 \mathrm{~m}$ at Zadní vrch). Similar deposits were observed in all three localities. The sediments form subhorizontal beds up to $2 \mathrm{~m}$ thick, represented by a poorly sorted polymictic (fragments of various types of basaltic rocks), coarse-grained (basaltic boulders up to $40 \mathrm{~cm}$ in diameter) matrix-supported debrite. The volcanigenic matrix consists of fine basaltic detritus and clinopyroxene crystals. The total thickness of the lahar deposits observed on the Jezerní hora Hill reaches $100 \mathrm{~m}$. Xenolithic clasts occur rarely, they were found in some depositional units of debrites around Klášterec and they consist of horizontally stretched violet clays with quartz crystals, most probably gneiss argillized by weathering already prior to the volcanic activity. The deposits contain abundant tree trunks, up to several meters long and $1 \mathrm{~m}$ in diameter, and fragments of tree branches. The trunks are distributed randomly in the host rock and subhorizontally orientated (Fig. 3). The number of trunks exposed during occasional excavations was not high enough to evaluate the possible preferred orientation statistically.

\section{Nechranice (locality 4 in Fig. 2)}

Opalized and calcified wood fragments occur at the base of fine- to medium-grained scoriae on the banks of the Nechranice dam on the southern slopes of the Čachovický vrch Hill. The geological classification was reconstructed on the basis of several small outcrops. The lower part of the section is accessible only when the Nechranice Lake is emptied during dry seasons. The basement of the profile consists of the fossil-weathered gneisse overlain by a pyroclastic deposit. Locally, relics of pre-volcanic sediments sandstones derived from crystalline rocks, are also present. The non-welded, loose pyroclastic rocks do not create a real outcrop there and the thickness can only be estimated as not exceeding $1 \mathrm{~m}$. The pyroclastic deposit consists of basaltic scoria fragments, $1-2 \mathrm{~cm}$ in diameter. The fragments of fossilized woods can only be found where pyroclastics occur. The fossilized wood was collected in an area $200 \times 20 \mathrm{~m}$, on the banks of the Nechranice Lake. The pyroclastic deposits are overlain by a few meters thick basanitic lava flow, which extends to the site from the top of Čachovický vrch Hill.

\section{Zvoníčkov (locality 5 in Fig. 2)}

Calcified tree trunks were found in the abandoned Zvoníčkov village among fragments of lacustrine travertine containing numerous cavities that originated from herbaceous stems. The travertine containing the tree trunks occurs in the valley amidst hills representing remnants of the DHVC lava sequences, but the contact is not exposed at present. We categorize this site as Early DHVC volcaniclastics on the basis of data obtained during the late $18^{\text {th }}$ and early $19^{\text {th }}$ century, when celadonite was exploited in the area of Zvoníčkov and eastern foothills of the Úhošt Hill. Großkopf (1932) and Müller (1936) described the sediments hosting the travertine as a sequence of alternating layers of tuffs, clays and limestone. The lithological scheme is supported by a 114 m deep borehole (Müller 1936).

\section{Geochronology}

Three monogenetic volcanoes from the latest phase of volcanic activity on the northern periphery of the DHVC were dated using the K-Ar method: Šumná Volcano, Blzeňský vrch Hill and Jelení vrch Hill. Despite the similar setting of the three volcanoes, their composition differs significantly. The lava of the Šumná volcano has a trachybasaltic composition, a picrobasalt erupted on the Jelení vrch scoria cone, the Čachovický vrch Hill is composed of an altered basanite (not suitable for K-Ar analysis) and a limburgite forms the Blzeňský vrch lava. The trachybasalt of the Šumná Volcano was sampled in the castle-trench on the top of the Šumná Hill (541 m a.s.1.). The remnant of a lava lake inside the scoria cone crater is exposed there. A picrobasalt feeder dyke of a scoria cone remnant crops out on the peak of the Jelení vrch Hill (363 m a.s.l.). Basanite lava was sampled in the active quarry currently occupying the entire Blzeňský vrch Hill. Suitable potassium concentrations produced reasonable data for the Šumná Volcano $(20.58 \pm 0.66 \mathrm{Ma})$ and the lava of Blzeňský vrch Hill $(22.51 \pm 1.06 \mathrm{Ma})$. The $\mathrm{K}_{2} \mathrm{O}$ content in the picrobasalt of the Jelení vrch Hill does not exceed $0.5 \%$. Hence, acceptable results could be obtained neither by processing a bulk-rock sample nor by processing the plagioclase/glass fraction separated from the groundmass.

The data obtained from Šumná volcano and Blzeňský vrch Hill yield an Aquitanian age and can be correlated with the youngest lava of the Úhošt Hill profile (22.09 \pm 0.73 Ma, Rapprich \& Holub 2008).

\section{Discussion on taphonomy and stratigraphy}

This paper focuses on fossilized wood from five sites from the north-eastern margins of the DHVC, representing three different types of volcaniclastic deposits (Fig. 2).

The area between the towns of Kadaň and Klášterec where the localities Zadní vrch Hill, Prostřední vrch Hill and Vernérov are situated (localities 1-3 in Fig. 2) - is mainly composed of polymictic volcanogenic debrites. These polymictic matrix-supported volcanogenic deposits 
with horizontally orientated tree trunks reflect sedimentation from debris flow - lahar. The older interpretation by Kopecký (e.g., 2010) considering maar volcanoes is rejected here because the debrites display no signs of phreatomagmatic fragmentation, xenolith content is low and their presence is limited solely to some layers and the debrites comprise subhorizontal beds of thickness up to $2 \mathrm{~m}$. On the other hand, diatreme breccias penetrating crystalline units should contain one type of basaltic rock (not various types of basaltic rocks as from the DHVC) and high content of upper-crustal xenoliths. Numerous types of volcanic rocks would be present only if diatreme penetrated the pre-existing volcanic sequence which is not the case in the northern DHVC periphery.

The lahars must have originated from a terrain with high relative elevation - most likely in the central part of the DHVC. The volcanic complex very probably reached altitudes of $1000 \mathrm{~m}$ a.s.l. in its central part at that time (the highest part of the early DHVC edifice is preserved in an erosional remnant on the Pustý zámek Hill, $927 \mathrm{~m}$ a.s.l. in the centre of the DHVC). The trees were dragged by the mass flows during their descent down the slopes of the volcano. The process may explain the high species diversity from the Zadní vrch Hill. The lower species diversity of the Prostřední vrch and Vernéřov localities is very probably due to the limited extent of occasional exposures. We consider Liriodendron-dominated forests to be typical of higher altitudes on the volcanic complex flanks as this wood type has not been observed in the lowland deposits surrounding the volcanic complex. Liriodendron today is a straight, tall tree, which is for two-thirds of the trunk freeof lateral branches and famous for its considerable height; nowadays it is the tallest of all Eastern United States angiosperm trees, and can attain $60 \mathrm{~m}$ in height (Beck 1990). We found a piece a trunk $40 \mathrm{~cm}$ in diameter (Fig. 3) which would roughly correspond to an at least $30 \mathrm{~m}$ tall tree (Beck 1990, table 1). The clastic material of the sediment is derived from the decay of an Early Ruppelian volcanic edifice. The lahars are overlain by a lava remnant (Rapprich 2007) correlated with lava dated $28.66 \pm 1.06 \mathrm{Ma}$ (Rapprich \& Holub 2008). Hence, we may suppose the age of the lahars as Late Ruppelian.

The lacustrine limestone (travertine) at Zvoníčkov containing platanoid wood forms intercalations in fine-grained volcaniclastics. These deposits are traditionally described as "tuffs", but no modern volcanological study has yet been focussed on them, mainly due to the absence of good exposures. The fine-grained volcaniclastics that underlie the Úhošt lavas can most probably be correlated with the fine-grained volcaniclastics with limestone intercalations known from the southeastern margins of the DHVC (mammal zone MP-21: Fejfar \& Kaiser 2005, i.e. $34 \mathrm{Ma}$ ). The fine-grained volcaniclastics at Zvoníčkov therefore represent products of early DHVC activity in the Early Ruppelian.

The coarse-grained and strongly vesiculated character of the pyroclasts at Nechranice reflects a local low-energy magmatic-gas driven volcanic eruption (Strombolian). The wood assemblage at Nechranice is relatively rich. It contains not only the types described above, but also new unidentified angiosperm wood (with at least three new types, probably related to subtropical Lauraceae and other families) and one silicified palm stem (No. 121/07), which are subject of ongoing studies. The plants were buried rapidly by the pyroclastic fall out. The subsequent lava effusion protected the accumulation from being eroded. The monogenetic volcanism on the northern periphery can be assigned to the Aquitanian according to the new data presented in this paper. However, we were not able to analyze exactly the Běchovický vrch Hill, the surrounding monogenic volcanoes yielding data within the range of $20.58 \pm 0.66$ to $22.51 \pm 1.06 \mathrm{Ma}$. The monogenic activity on the northern margin of the DHVC was contemporaneous with the youngest lava of the Úhošt profile (Rapprich \& Holub 2008).

\section{Conclusions}

We have distinguished three types of deposits reflecting three different volcanic environments: 1) lahar deposits on the Zadní vrch Hill, Prostřední vrch Hill and at Vernéřov, 2) pyroclastic deposits of a local monogenic cone at Nechranice and 3) lacustrine sediments on a plain at the foot of the volcano near Zvoníčkov. The obtained K-Ar ages for the monogenic cones on the DHVC northern periphery are the youngest among the volcanic rocks of the entire

Figure 5. A, B - Wood type 4 -Cercidiphylloxylon (epitype G8113 of Cercidiphylloxylon kadanense). • A - diffuse-porous wood with mostly solitary vessels, angular in outline. TS. $\bullet \mathrm{B}$ - detail of a long scalariform perforation plate with about 50 bars, TLS. $\bullet$ C - Wood type $5-U l m u s$ (specimen $75 / 04$ ): Outer part of a ring-porous wood with mainly solitary earlywood vessels and latewood vessels in wavy tangential bands, TS. • D-G - Wood type 6 - ?Craigia (D-F: specimen 72/03; G: specimen 89/04). $\bullet$ D - Wood semi-ring porous with folded earlywood vessels, TS. $\bullet$ E - strongly heterocellular rays with tile cells, TLS. $\bullet$ F - detail of tile cells of Pterospermum type, RLS. $\bullet$ G - coalescent apertures of alternate intervessel pits mimicking helical thickening, TLS. $\bullet \mathrm{H}-\mathrm{M}$ - Wood type 7 - Coryloxylon (H-J: holotype CNB-4 of Coryloxylon nemejcii; K-M: holotype CNB-3 of Coryloxylon tertiarum). - H, K - diffuse-porous wood with numerous vessels in radial multiples, TS. • I, L - mostly 3-4-seriate strongly heterocellular rays, TLS. • J - two scalariform perforation plates with less than 20 bars in the middle, RLS. $\bullet$ M - scalariform perforation plate with less than 20 bars from a side view, TLS. Scale bars $=500 \mu \mathrm{m}$ in A, C, D, H, K; $200 \mu \mathrm{m}$ in E, F, I, L; $100 \mu \mathrm{m}$ in B, G, J, M. 

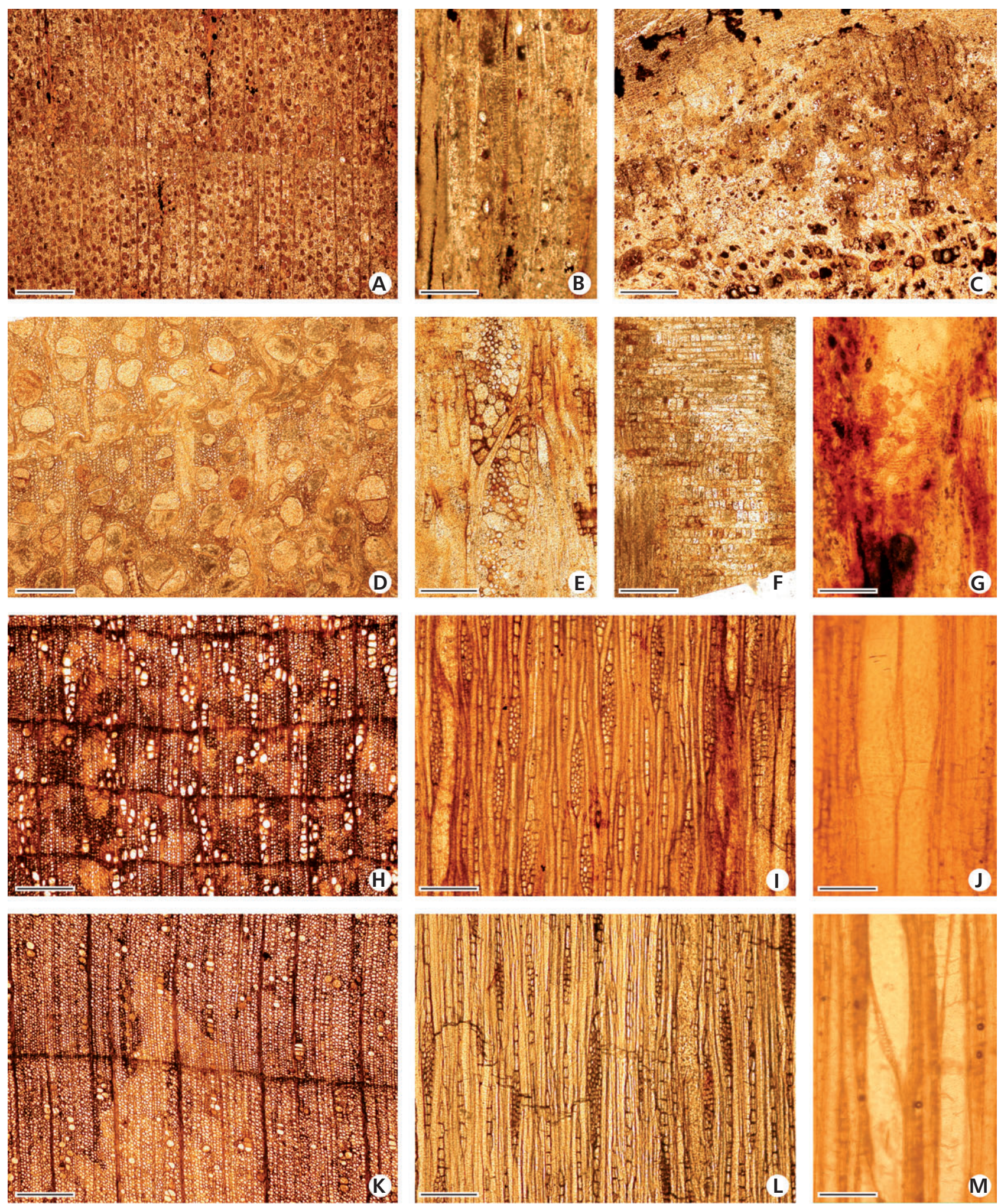
complex. The data confirm the geological position of the monogenic cones and support the stratigraphic classification of the flora from the Nechranice site.

A re-examination of the type material as well as the new collections show that some taxa determined earlier should be combined forming 'natural' taxa. This is the case for Platanoxylon bohemicum, Spiroplatanoxylon europaeum and Dryoxylon bohemicum which belong to one type of platanoid wood, probably related to Platanus neptuni and also Coryloxylon nemejcii and C. tertiarum which represent only one wood type related to the genera Styrax and Halesia of the Styracaceae. On the other hand, two new types are described: Ulmus (Ulmaceae) and tentative Craigia (Malvaceae s.1.). As a result, there are at present seven well defined species / types of fossil angiosperm wood recognized in the studied area of the DHVC.

The lahar deposits and the lacustrine limestones appear to be similar in age. We may suppose that during the Rupelian, Platanus-type woods dominated lower altitudes whereas Liriodendron occupied the slopes and higher altitudes of the repeatedly growing and decaying volcanic complex. The lowlands, represented here by the Nechranice area, show a mixture of various species including some thermophilous elements such as subtropical Lauraceae and palms.

\section{Acknowledgments}

The present paper greatly benefited from the valuable comments and suggestions given by C. Privé-Gill, Z. Kvaček, M. \& J. Dupéron, V. Gryc and E.A. Wheeler. We are also grateful to Z. Dvořák, F. Foltýn, P. Coufal, O. Janeček, B. Zasadil and $\breve{S}$. Sahaj for the fossil wood material and information regarding its geological setting. The manuscript was greatly improved by the thorough reviews of E.A. Wheeler, P. Suhr and an anonymous reviewer. The research was financially supported by the grants GA205/08/0643 (Czech Science Foundation) and IAA300130612 (Grant Agency of the Czech Academy of Sciences) and was carried out within the framework of institutional research plans MSM0021620855 (Faculty of Science, Charles University) and MZP0002579801 (Czech Geological Survey). The K-Ar analytical work was partly supported by the Hungarian National Scientific Fund (OTKA No. K68153).

\section{References}

BALOGH, K. 1985. K/Ar dating of Neogene volcanic activity in Hungary: experimental technique, experiences and methods of chronologic studies. ATOMKI Reports D/1, 277-288.

BECK, D.E. 1990. Liriodendron tulipifera L., Yellow-Poplar, Magnoliaceae - Magnolia family, 801-822. In BURNS, R.M. \& Honkala, B. (tech. coords.) Silvics of North America: 2. Hardwoods. U.S. Department of Agriculture, Forest Service, Washington D.C., http://www.na.fs.fed.us/spfo/pubs/silvics_ manual/volume_2/silvics_v2.pdf.
Brett, D.W. 1972. Fossil wood of Platanus from the British Eocene. Palaeontology 15, 496-500.

BƯŽEK, Č., HOLÝ, F. \& KVAČEK, Z. 1996. Early Miocene flora of the Cypris Shale (western Bohemia). Acta Musei nationalis Pragae, Series B - Historia naturalis 52, 1-72.

CAmeron, K.A. \& Pringle, P. 1986. Post-Glacial lahars of the Sandy River Basin, Mount Hood, Oregon. Northwest Science 60, 225-237.

DiCKISON, W.C. \& PHEND, K.D. 1985. Wood anatomy of the Styracaceae: evolutionary and ecological considerations. IAWA Bulletin new series 6, 3-22.

Dupéron, J., Dupéron-Laudoueneix, M., SAKala, J. \& DE FRANCESCHI, D. 2008. Ulminium diluviale Unger: historique de la découverte et nouvelle étude. Annales de Paléontologie 94, 1-12. DOI 10.1016/j.annpal.2007.12.003

Dupéron-Laudoueneix, M. \& Dupéron, J. 2005. Bois fossiles de Lauraceae: nouvelle découverte au Cameroun, inventaire et discussion. Annales de Paléontologie 91, 127-151. DOI 10.1016/j.annpal.2005.03.002

FEJFAR, O. \& KAISER, T.M. 2005. Insect bone-modification and paleoecology of Oligocene mammal-bearing sites in the Doupov Mountains, Northwestern Bohemia. Palaeontologia Electronica 8(1), http://palaeo-electronica.org, 1-11.

GROßKOPF, W. 1932. Geologie-Erdgeschichte der Komotauer Landschaft. 94 pp. Deutscher Bezirkslehrerverein Komotau Verlag, Komotau.

HRADECKÝ, P. 1997a. The Doupov Mountains, 125-127. In VRÁNA, S. \& ŠTĚDRÁ, V. (eds) Geological Model of Western Bohemia Related to the KTB Borehole in Germany, Journal of the Geological Sciences, Geology 47.

HRADECKÝ, P. 1997b. Lahars in Doupovské hory Mts. Geoscience Research Reports for 1996, 53-55. [in Czech with English abstract]

IAWA COMMITTEE 1989. IAWA list of microscopic features for hardwood identification. IAWA Bulletin new series 10, 219-232.

INSIDEWOOD 2004-onwards. Published on the Internet. http://insidewood.lib.ncsu.edu/search/ (December 8, 2006)

KOPECKÝ, L. 2010. České středohoři Mts and ambient young alkaline volcanic complexes in the Ohře Rift, Czech Republic: volcanology, petrology and rift evolution. $188 \mathrm{pp}$. Czech Geological Survey, Praha.

KVAČEK, Z. 2008. Whole-plant reconstructions in fossil angiosperm research. International Journal of Plant Sciences 169, 918-927. DOI 10.1086/589694

KVAČEK, Z., DVOŘÁK, Z., MACH, K. \& SAKALA, J. 2004. Tertiary plants of the North-Bohemian brown-coal basin. 160 pp. Severočeské doly \& Granit, Chomutov \& Praha. [in Czech]

KVAČEK, Z. \& MANCHESTER, S.R. 2004. Vegetative and reproductive structure of the extinct Platanus neptuni from the Tertiary of Europe and relationships within the Platanaceae. Plant Systematics and Evolution 244, 1-29.

DOI 10.1007/s00606-003-0082-2

KVAČEK, Z., MANCHESTER, S.R. \& GUO, S.-X. 2001. Trifoliolate Leaves of Platanus bella (Heer) comb. n. from the Paleocene of North America, Greenland, and Asia and Their Relationships among Extinct and Extant Platanaceae. International Journal of Plant Sciences 162, 441-458.

DOI $10.1086 / 319574$ 
KVAČEK, Z. \& TEODORIDIS, V. 2007. Tertiary macrofloras of the Bohemian Massif: a review with correlations within Boreal and Central Europe. Bulletin of Geosciences 82(4), 383-408. DOI 10.3140/bull.geosci.2007.04.383

MANCHESTER, S.R. 1980. Chattawaya (Sterculiaceae): A new genus of wood from the Eocene of Oregon and its implication for xylem evolution of the extant genus Pterospermum. American Journal of Botany 67, 59-67. DOI 10.2307/2442537

MANCHESTER, S.R., CHEN, Z. \& ZHOU, Z. 2006. Wood anatomy of Craigia (Malvales) from southeastern Yunnan, China. IAWA Journal 27, 129-136.

MLČOCH, B. 2003. Character of the Contact between the Saxothuringian and Teplá-Barrandian Unit. Geolines 16, 75.

MLČOCH, B. \& KONOPÁSEK, J. 2010. Pre-Late Carboniferous geology along the contact of the Saxothuringian and TepláBarrandian zones in the area covered by younger sediments and volcanics (western Bohemian Massif, Czech Republic). Journal of Geosciences 55, 81-94. DOI 10.3190/jgeosci.068

MÜLLER, B. 1936. Neue forschungen im böhmischen Tertiär. Mitteilungen des Vereines der Naturfreunde in Reichenberg $58,14-33$.

ODIN, G.S. 1982. Numerical Dating in Stratigraphy. 1040 pp. John Wiley and Sons, New York.

OLsON, M.E. 2005. Commentary: Typology, homology, and homoplasy in comparative wood anatomy. IAWA Journal 26, 507-522.

PRAKASH, U., BŘEZINOVÁ, D. \& BƯŽEK, Č. 1971. Fossil woods from the Doupovské hory and České středohoří Mountains in Northern Bohemia. Palaeontographica, Abteilung B 133, $103-128$.

RAPPRICH, V. 2007. Volcanic processes in the surroundings of Kadaň. Geoscience Research Reports for 2006, 34-36. [in Czech with English abstract]

RAPPRICH, V. \& HOLUB, F.V. 2008. Geochemical variations within the Upper Oligocene - Lower Miocene lava succession of Úhošt Hill (NE margin of Doupovské hory Mts., Czech Republic). Geological Quarterly 52, 253-268.

RiCHTER, H.G. 1987. Mature secondary xylem, 162-168. In MetCAlfe, C.R. (ed.) Anatomy of the Dicotyledons, vol. 3., Magnoliales, Illiciales, and Laurales (second edition). Clarendon Press, Oxford.

SAKALA, J. 2002. First record of fossil angiosperm wood (Ulmoxylon, Ulmaceae) from the famous locality of Bílina (Czech Republic, Early Miocene). Comptes Rendus Palevol 1, 161-166. DOI 10.1016/S1631-0683(02)00025-8

SAKALA, J. 2006. Re-evaluation of the fossil angiosperm wood from the area of Kadaň (Oligocene of northwestern Bohemia, Czech Republic). Scripta Facultatis Scientiarum Naturalium Universitatis Masarykianae Brunensis, Geology 33-34, 74.
SAKALA, J. 2007. The potential of the fossil angiosperm wood to reconstruct the palaeoclimate in the Tertiary of Central Europe (Czech Republic, Germany). Acta Palaeobotanica 47, 127-133.

SAKAlA, J. \& PRIVÉ-GILl, C. 2004. Oligocene angiosperm woods from northwestern Bohemia, Czech Republic. IAWA Journal 25, 369-380.

SELMEIER, A. 2000. Structural variation of Tertiary Grewia woods (Tiliaceae) from the East Bavarian Molasse, Germany. Feddes Repertorium 111, 465-480. DOI 10.1002/fedr.20001110713

STEIGER, R.H. \& JÄGER, E. 1977. Subcommission on geochronology: convention on the use of decay constants in geo- and cosmochronology. Earth and Planetary Science Letters 36, 359-362. DOI 10.1016/0012-821X(77)90060-7

SÜSS, H. 2007. Holzfossilien der Morphogattung Spiroplatanoxylon gen. nov. aus dem Tertiär von Europa und Vorderasien. Feddes Repertorium 118, 1-19. DOI 10.1002/fedr.200711121

SÜSS, H. \& MÜLLER-STOLL, W.R. 1977. Untersuchungen über fossile Platanenhölzer. Beiträge zu einer Monographie der Gattung Platanoxylon Andreánszky. Feddes Repertorium 88, 1-62. DOI 10.1002/fedr.19770880102

TEODORIDIS, V. \& SAKALA, J. 2008. Early Miocene conifer macrofossils from the Most Basin (Czech Republic). Neues Jahrbuch für Geologie und Paläontologie, Abhandlungen 250, 287-312. DOI 10.1127/0077-7749/2008/0250-0287

TERADA, K. \& SUZUKI, M. 1998. Revision of the so-called "Reevesia" fossil woods from the Tertiary in Japan - a proposal of new genus Wataria (Sterculiaceae). Review of Palaeobotany and Palynology 103, 235-251.

DOI 10.1016/S0034-6667(98)00039-6

UlRYCH, J., SVOBODOVÁ, J. \& BALOGH, K. 2002. The source of Cenozoic volcanism in the České středohoří Mts., Bohemian Massif. Neues Jahrbuch für Mineralogie, Abhandlungen 177, 133-162. DOI 10.1127/0077-7757/2002/0177-0133

WHEELER, E.A. 1995. Wood of Platanus kerrii. IAWA Journal $16,127-132$.

WHEELER, E.A. \& MANCHESTER, S.R. 2002. Woods of the Eocene Nut Beds Flora, Clarno Formation, Oregon, USA. IAWA Journal, Supplement 3, 1-188.

WHEELER, E.A. \& MANCHESTER, S.R. 2007. Review of the wood anatomy of extant Ulmaceae as context for new reports of Late Eocene Ulmus woods. Bulletin of Geosciences 82, 329-342. DOI 10.3140/bull.geosci.2007.04.329

WiemanN, M.C., WheEler, E.A., MANChESTER, S.R. \& PORTIER, K.M. 1998. Dicotyledonous wood anatomical characters as predictors of climate. Palaeogeography, Palaeoclimatology, Palaeoecology 139, 83-100.

DOI 10.1016/S0031-0182(97)00100-4 
